Studia z Dziejów Średniowiecza, t. 24, 2020

\author{
Maciej Wojcieszak \\ (Uniwersytet Gdański)
}

https://orcid.org/000-0002-8150-9751

\title{
Kościół późnoantyczny \\ i wczesnośredniowieczny wobec problemu niechcianych dzieci w świetle postanowień zachodniorzymskich zgromadzeń biskupich ${ }^{1}$
}

https://doi.org/10.26881/sds.2020.24.12

Keywords: The Church in late antiquity and the early Middle Ages, unwanted children, bishops' assemblies

Czwarte i piąte stulecie w Cesarstwie Rzymskim stanowiły okres intensywnej transformacji gospodarczej, politycznej i społecznej. Wpływ na to miały barbarzyńskie najazdy, konflikt z Persja, częste uzurpacje cesarskie oraz zmiany dokonywane przez rządzących w kwestiach religijnych ${ }^{2}$. Decyzje Konstantyna Wielkiego oraz kolej-

1 W przypisach zastosowano następujące skróty: AJLH - „American Journal of Legal History”; CCSL - Corpus Christianorum Series Latina; CIC I - Corpus Iuri Canonici, vol. I; Cod. Iust. - Codex Iustinianus; Cod. Th. - Codex Theodosianus; JLR - „Journal of Law and Religion”; RBL - „Ruch Biblijny i Liturgiczny”; SCL I - Synodi et Collectiones Legum, vol. I, Acta Synodalia ann. 50-381; SCL I - Synodi et Collectiones; CSEL - Corpus Scriptorum Ecclesiasticorum Latinorum; JECS - „Journal of Early Christian Studies”; PG - Patrologia Graeca; PL - Patrologia Latina; SCh - Sources Chrétiennes Legum, vol. II, Constitutiones Apostolorum; SCL III - Synodi et Collectiones Legum, vol. III, Canones Patrum Graecorum; SCL IV - Synodi et Collectiones Legum, vol. IV, Acta Synodalia ann. 381431; SCL VI - Synodi et Collectiones Legum, vol. VI, Acta Synodalia ann. 431-504; SCL VIII - Synodi et Collectiones Legum, vol. VIII, Acta Synodalia ann. 506-553; VoxP - „Vox Patrum”; WST - „Warszawskie Studia Teologiczne”.

2 Por. A. Goldsworthy, Pax Romana. Wojna, pokój i podboje w świecie rzymskim, Poznań 2020, s. 464-466. 
nych cesarzy ukształtowały dominującą rolę religii chrześcijańskiej w Cesarstwie Rzymskim, co nie oznaczało oczywiście, że religie pogańskie oraz judaizm przestały istnieć, a problem nawróceń koniunkturalnych z wierzeń pogańskich był widoczny w różnej skali aż do epoki średniowiecznej ${ }^{3}$.

Koniec panowania Romulusa Augustulusa w 476 r. najpewniej nie został nawet zauważony przez mieszkańców zachodniej części Imperium $^{4}$, bo większość prowincji oddzieliła się od centrum Cesarstwa jeszcze przed tą data, dlatego dla ludzi ówczesnych czasów ta cezura nie stanowiła jakiegoś wyznacznika nowej epoki. Nikt wtedy nie przypuszczał, że jest świadkiem narodzin nowej epoki. W VI w., mimo przemian związanych z ostatecznym upadkiem struktur Cesarstwa na Zachodzie, hierarchia kościelna nadal zbierała się na synodach, tylko że w zmienionej mozaice politycznej. Rodził się nowy porządek europejski wprowadzany przez królów barbarzyńskich, jednak poruszane problemy społeczne pozostawały bez zmian. Grupa źródeł dokumentacji zgromadzeń biskupich stanowi ważna pomoc w rekonstruowaniu fragmentów obrazu społeczeństwa późnoantycznej i wczesnośredniowiecznej zachodniej Europy.

Duchowieństwo chrześcijańskie zaczęło mieć niebagatelny wpływ na życie rzymskiego społeczeństwa, nie tylko w kwestiach religijnych, ale również etyki i moralności ${ }^{5}$. Zaczęto dążyć także do uregulowania wszelkich spornych kwestii w chrześcijaństwie, a dokonywano tego podczas uchwalania kanonów w trakcie obrad zgromadzeń biskupich, których już w samym IV w. odbyło się ponad sto osiemdziesiąt ${ }^{6}$. Należy pamiętać o zasadniczej różnicy

$3 \mathrm{Na}$ ten temat por. The Conflict between Paganism and Christians in the Fourth Century, ed. A. Momigliano, Oxford 1963; The Christianity and Paganism, 350-750. Conversion of Western Europe, ed. J.N. Hillgarth, Philadelphia 1986.

4 Wschodni historycy kościelni są w tej kwestii interesującym przykładem. Hermiasz Sozomen i Sokrates Scholastyk wspominają o tym wydarzeniu, nie poświęcając mu wiele miejsca, jednak niektórzy w ogóle je pomijaja, co udowadnia nam niezachowana niestety Historia Ecclesiastica Bazylego z Cylicji, opisujacca lata 415-517, a znana dzięki pracy Biblioteka Focjusza z IX w. Jeżeli przyjać za prawdziwą relację Focjusza, Bazyli z Cylicji nie wspomniał o upadku Rzymu za czasów Symplicjusza, bardziej skupiając się na jego śmierci w 483 r., por. Photius, Bibliotheke, Cod. 42, PG 103.

5 R. Paporski, Kapłaństwo w starożytnym świecie grecko-rzymskim, VoxP 1993-1995, t. $13-15$, z. 24 , s. 34 .

6 Por. J. Woch, Biskup Rzymu wobec problemów Kościołów wschodnich przy końcu IV w., VoxP 2004, t. 46-47, s. 244-245. Samo zaś pojęcie kanonu było tożsame z pojedynczą decyzją synodu lub soboru (które to sobory w zachodniej części 
pomiędzy zgromadzeniami lokalnymi - głównie wydajacymi przepisy dotyczące podległej sobie prowincji kościelnej i zajmującymi się w ramach tej prowincji działalnością dyscyplinarna (synodami) a zgromadzeniami powszechnymi (soborami), które wydawały uchwały mające obowiązywać chrześcijan zarówno na wschodzie, jak i na zachodzie ${ }^{7}$.

Problematyką dotyczącą niechcianych dzieci w okresie późnoantycznym i wczesnośredniowiecznym zajmowało się już wielu polskich oraz zagranicznych autorów ${ }^{8}$. O ustawach synodalnych dotyczących porzucanych dzieci również wspominano w polskich i zagranicznych monografiach, ale nie stanowiły one osobnego tematu, sa natomiast przedmiotem niniejszego opracowania. Zajęliśmy się kwestią niechcianych dzieci, którą podnoszono podczas synodów geograficznie znajdujących się na obszarze zachodniej części Cesarstwa Rzymskiego także i po 476 r. Na tej podstawie spróbowaliśmy oddać stanowisko Kościoła w epoce późnego antyku wobec trudnego problemu związanego z niechcianymi dziećmi oraz odpowiedzieć na pytanie, jakie dzieci uznawano za niechciane. Postanowienia kanonów zostały omówione chronologiczne. Dla uzupełnienia badań w miejscach problematycznych posiłkowaliśmy się analogicznymi dokumentami ze wschodniej części Cesarstwa Rzymskiego.

Cesarstwa się nie odbywały) dotycząca świata chrześcijańskiego w każdej problematyce, por. J. Assmann, Pamięć kulturowa. Pismo, zapamiętywanie i tożsamość polityczna $w$ cywilizacjach starożytnych, Warszawa 2008, s. 125-126.

7 Na temat synodów i soborów w interesującym nas okresie por. P.T-H. Camelot, Éphèse et Chalcédoine, Paris 1962; L.D. Davis, The First Seven Ecumenical Councils (325-787): Their History and Theology, Wilmington 1988; K. Ilski, Sobory $w$ polityce religijnej Teodozjusza II, Poznań 1992; S. Bralewski, Imperatorzy późnego cesarstwa rzymskiego wobec zgromadzeń biskupów, Łódź 1997; F. Bechau, Historia soborów, Kraków 1998; J.N.D. Kelly, Poczqtki doktryny chrześcijańskiej, Warszawa 1999; K. Schatz, Sobory powszechne. Punkty zwrotne w historii Kościoła, Kraków 2001; H. Pietras, Sobór Nicejski (325). Kontekst religijny i polityczny, dokumenty, komentarze, Kraków 2013; M. Starowieyski, Sobory niepodzielonego Kościoła, Kraków 2016.

8 Por. J. Boswell, The Kindness of Strangers. The Abandonment Children in Western Europe from Late Antiquity to the Renaissance, New York 1988, s. 51-266; C. Tate, Christianity and Legal Status of Abandoned Children in the Later Roman Empire, JLR 2008, vol. 24/1, s. 123-141; A. Muszala, Embrion ludzki $w$ starożytnej refleksji teologicznej, Kraków 2009, s. 459-466; M. Starowieyski, Ojcowie Kościoła i starożytne Sobory, Kraków 2019, s. 280-282, 300-302; Y. Monnickendam, The Exposed Child: Transplanting Roman Law into Late Antique Jewish and Christian Legal Discourse, AJLH 2019, vol. 59, s. 1-30. 
Stosunek społeczeństwa antycznego do przerywania ciąży i porzucania dzieci był różny. Filozofowie oraz lekarze świata grecko-rzymskiego odnosili się do tych zagadnień, biorąc pod uwagę przede wszystkim życie matki, jej pochodzenie, sytuację materialna i inne czynniki warunkujące aborcję oraz porzucenie dziecka ${ }^{9}$. Trzeba również pamiętać, że prawo rzymskie pozwalało ojcu na zabicie dziecka, jeśli popełniło ono wykroczenie, aczkolwiek o relacjach na linii ojciec-dziecko w okresie późnego antyku i wczesnego średniowiecza mamy niewiele materiałów ${ }^{10}$. Kościół jednoznacznie zaś potępiał takie działania - zarówno prawo ojca do zabicia dziecka, jak i aborcję lub porzucenie dziecka.

$\mathrm{W}$ interesujacym nas okresie jako pierwsi problem niechcianych dzieci poruszyli biskupi hiszpańscy zebrani na synodzie w Elwirze (dzisiejsza Grenada) około 306 r. ${ }^{11} \mathrm{~W}$ kanonie 63 czytamy, że chrześcijańskie kobiety zabijające dzieci zaraz po porodzie miały otrzymywać karę ekskomuniki i były pozbawiane komunii z Kościołem na zawsze ${ }^{12}$. Za ten czyn podobnie surowo traktowano katechumenki. Jeśli biskup widział, że życie katechumenki zbliżało się do końca, wówczas dopiero mógł udzielić jej chrztu ${ }^{13}$. Możemy się domyślać, że nie chodziło tutaj tylko o zabójstwo po porodzie, a biskupi odwoływali się także do wywołanego wcześniej sztucznie porodu lub poronienia. Treść kanonów dotyczyła dzieci wszystkich warstw społecznych poczętych w cudzołóstwie, a zatem tych, które

9 Por. E. Nardi, Procurato aborto nel mondo greco-romano, Milano 1971; L. Bielas, Dziecko przed urodzeniem w starożytnym świecie pogańskim, „Roczniki Biblioteczne” 1991, R. 44, s. 37-46; J. Gula, O przerywaniu ciąży w starożytności. Kilka uwag polemicznych, „Ethos” 1995, nr 31-32, s. 247-253.

10 Por. M. Kosznicki, Obraz ojca-filozofa w późnoantycznych mowach Temistiusza [w:] Społeczeństwo i religia w świecie antycznym. Materiały z ogólnopolskiej konferencji naukowej (Toruń 20-22 września 2007 r.), red. Sz. Olszaniec, S. Wojciechowski, Torun 2010, s. 401-408.

11 Datowanie pierwszego synodu obradującego w prowincji hiszpańskiej wciąż pozostaje niepewne. Na ten temat por. L. Duchesne, Le concile d'Elvira et les flamines chrétiennes, Paris 1887, s. 159-174; V. de Clercq, Samuel Laeuchli, Power and Sexuality. The Emergence of Canon Law at the Synod of Elvira (review), „Vigiliae Christianae” 1975, no. 1, vol. 29, s. 76; J.F. Ubina, Le concile d'Elvire et l'esprit du paganisme, „Dialogues d'histoire ancienne” 1993, vol. 19/1, s. 309-318. Na temat samego synodu por. M. Meigne, Concile ou collection d'Elvire, „Revue d'Histoire Ecclesiastique" 1975, vol. 70, s. 361-387.

12 SCL I, s. 59, can. 63, Elvira (306). Dosłownie tam czytamy, że dziecko spłodzone podczas ,absente marito [...] idque post facinus occiderit”.

13 SCL I, s. 60, can. 68, Elvira (306). Czytamy tam, że „placuit eamin fine bapitzari”. 
miały status bękartów. Kobiety takie zabijały swoje dzieci po porodzie z różnych przyczyn. Pragnęły zapewne ustrzec się przed gniewem męża (jeśli były w związku małżeńskim), oskarżeniami społeczności, w której żyły, lub nie potrafiły zapewnić sobie i dziecku minimum egzystencjalnego ${ }^{14}$. Być może były także namawiane do zabójstwa dzieci przez mężczyzn będących sprawcami ich ciąż ${ }^{15}$. Do ojca bowiem, zgodnie z rzymskim prawem, należała także decyzja, czy dziecko zostanie uznane, czy nie ${ }^{16}$. Rygoryzm kanonów z Elwiry wynikał z sytuacji, którą spowodowały prześladowania ${ }^{17}$.

Kwestię aborcji roztrząsano również na synodzie w Ancyrze w 314 r., gdzie biskupi ustalili łagodniejszą karę 10 lat pokuty dla kobiety, która dokonała zabójstwa dziecka po porodzie ${ }^{18}$. Cesarze Walentynian II, Walens i Gracjan wydali prawo w 374 r. mówiące, że każde bez wyjątku zabójstwo dziecka sprowadzi na sprawcę karę śmierci, jednak - jak pisze Jan Iluk - rzymskie prawo karne „wykazywało wyjątkową odporność na czynione przez Kościół zabiegi objęcia aborcji kwalifikacją dzieciobójstwa"19. Aborcja musiała zapewne stanowić dość powszechny problem w późnoantycznym Cesarstwie, zależny od kontekstu ekonomiczno-społecznego ${ }^{20}$. Niemniej od momentu uchwalenia kanonów przez synody w Elwirze

14 Por. M. Pawlak, Rodzina [w:] Świat rzymski $w$ V wieku, red. R. Kosiński, K. Twardowski, Kraków 2009, s. 318-319.

15 Biskupi nie poruszyli jednak w żaden sposób tego tematu. W jednym z kanonów pisali jedynie, że cudzołożnych mężczyzn należy ukarać pięcioletnią pokutą. W treści kanonu nie odnajdziemy jednak problematyki niechcianych dzieci poczętych w cudzołóstwie, por. SCL I, s. 60, can. 69, Elvira (306).

16 Por. J. Carcopino, Życie codzienne $w$ Rzymie $w$ okresie rozkwitu cesarstwa, Warszawa 1966, s. 84-85.

17 Por. M. Meigne, Concile ou collection d'Elvire..., s. 361-363.

18 SCL I, s. 67, can. 21, Ancyra (314).

19 Por. J. Iluk, Chrześcijańskie matżeństwo i rodzina w rzymskiej starożytności [w:] W. Pałubicki, J. Iluk, Matżeństwo i rodzina $w$ dawnym judaizmie i starożytnym chrześcijaństwie, Gdańsk 1995, s. 216-217.

20 Na temat aborcji w interesującej nas epoce por. S. Longosz, Ojcowie Kościoła a przerywanie ciaży, VoxP 1985, t. 5, z. 8-9, s. 231-273; E. Staniek, Stosunek chrześcijan starożytnych do dziecka przed jego narodzeniem wedtug Ojców Kościoła, RBL 1991, t. 44, nr 1-3, s. 47-53; M. Starowieyski, Aborcja w opinii pierwszych chrześcijan, „Studia Paradyjskie” 1993, t. 3, s. 107-128; I. Milewski, Obyczaje życia codziennego chrześcijan drugiej połowy IV wieku w świetle pism Bazylego Wielkiego, VoxP 1997, t. 17, z. 32-33, s. 109-110; M. Starowieyski, Aborcja i życie nienarodzonych w starożytności chrześcijańskiej, WST 2009, t. 22, nr 1, s. 117-147; R. Sala, Poczatki życia ludzkiego $w$ komentarzach patrystycznych, „Polonia Sacra” 2013, R. $17, \mathrm{nr}$ 1(32), s. 51-70. 
i Ancyrze zostały wydane dopiero na synodzie w hiszpańskiej Leridzie w $546 \mathrm{r}^{21}$, co nie oznacza, że nie interesowano się tym tematem, a jedynie, iż nie wszystkie kolekcje praw zostały zachowane do czasów współczesnych. Niemniej postanowień z synodu w Elwirze nie uznano za obowiązujące, a posiłkowano się na zachodzie kanonami z Ancyry, prawdopodobnie nie widząc konieczności dokonywania zmian ${ }^{22}$. Mimo wszystko recepcja kanonów wschodnich na zachodzie była niewielka z powodu zanikającej znajomości greki oraz rosnacych uprzedzeń teologicznych.

Augustyn z Hippony jednoznacznie poteppiał kobiety dokonujace aborcji ${ }^{23}$. Biskupa Hippony dopuszczał aborcję tylko, gdy ciąża zagrażała życiu matki ${ }^{24}$. Często jednak ją przeprowadzano, ponieważ dziecko było niechciane ${ }^{25}$. Aborcje wykonywano, wycinając płód część po części, a następnie wyjmowano z macicy przez pochwę ${ }^{26}$. Jeśli zaś z powodów finansowych lub religijnych aborcja nie była możliwa, to niechciane dzieci, zgodnie z relacją Augustyna, najczęściej sprzedawano ${ }^{27}$.

Zdarzało się, że na duchownych wyświęcano już żonatych mężczyzn, którzy w swoich społecznościach pełnili ważne funkcje ${ }^{28}$. Kwestia ta wiązała się także z poważnym problemem wyższych stopni duchowieństwa. Diakoni i wyżsi duchowni nie mogli

21 Por. J. Vives, Concilios visigóticos e hispano-romanos, Barcelona-Madrid 1962, s. 55; E. Nardi, Procurato aborto nel mondo greco-romano, Milano 1971, s. 619. Aborcja zaprzątała przede wszystkim uwagę ówczesnych Ojców Kościoła, hierarchowie zaś uznali, że wydane przepisy na początku IV w. będą obowiązujące i nie należy ich zmieniać. Oczywiście, jak pisał Bazyli Wielki w swoich kanonach, każda sytuację aborcji należało rozsądzać w kontekście życia danej kobiety, por. Basilius Magnus, can. 2, SCL III, s. 35.

22 Całościowe opracowanie tego tematu z punktu widzenia środowisk pogańskich i chrześcijańskich w interesującym nas okresie por. F.J. Dölger, Das Lebensrecht des ungeborenen Kindes und die Fruchtabtreibung in der Bewertung der heidnischen und christlichen Antike, „Antike und Christentum. Kultur und Religionsgeschichtliche Studien” 1980 (2. Aufl.), Bd. 4, s. 1-61.

23 Augustinus, De nuptiis et conupiscentia, I, 15, 17, PL 44.

24 Augustinus, Enchiridion LXXXVI, PL 40.

25 Ibidem.

26 Augustinus, Enchiridion LXXXVI, PL 40.

27 Augustinus, De coniugiis adulterinis, I, 15, 17, PL 40.

28 Por. M. Wojcieszak, Moralność matżeńska i seksualna świeckich oraz duchownych w świetle ustaleń wschodniorzymskich zgromadzeń biskupich [w:] Interakcje polityczno-kulturowe i religijne $w$ dziejach starożytnych, red. M. Podrazik, R.S. Wójcikowski, Rzeszów 2015, s. 132-135. 
bowiem po awansie współżyć z małżonkami ${ }^{29}$. Zazwyczaj łamanie kanonów dotyczących pożycia małżeńskiego duchowieństwa pozostawało tajemnica alkowy, jednak w momencie poczęcia dziecka trudno było ten fakt przed wiernymi ukryć. Duchowni obradujacy w Turynie w 398 r. zakazali takim kapłanom awansu w hierarchii kościelnej ${ }^{30}$. Analogiczne ustalenia podjęli również biskupi w Toledo w 400 r. ${ }^{31}$ Podobne decyzje wydały synody obradujace na terenach Galii w Valence-d'Agen w 374 r. i Orange w 441 r. ${ }^{32}$ Zakazy te zostały powtórzone w kanonie 4 wydanym podczas piątego synodu w Orleanie w $549 \mathrm{r} \cdot{ }^{33}$ Widzimy więc, że niektóre poczęte przez duchownych dzieci mogły stawać się niechcianymi i być przez nich traktowane jak bękarty w momencie, gdy ci awansowali do wyższych struktur kościelnych.

Obawa przed spłodzeniem bękarta motywowała zapewne również biskupów obradujących w Kartaginie w 418 r., którzy zezwolili na wcześniejsze przywdzianie welonu dziewczynie, której cnocie zagrażałby uwodziciel lub rozpustnik ${ }^{34}$. W treści kanonu nie doprecyzowano jednak szczegółów trudnej sytuacji. Jedynie, aby nie wzbudzać plotek i nie dawać okazji do cudzołóstwa, biskupi pozwalali przejść do stanu zakonnego tym dziewczynom, które nie ukończyły jeszcze 25 lat $^{35}$. Na ile były to działania motywowane

29 Było to tylko powtórzenie przepisów z pierwszego soboru nicejskiego w $325 \mathrm{r}$. (kanony 4 i 9). Powtarzanie kanonów świadczy o tym, że duchowieństwo ich nie przestrzegało, ale nie tylko o tym. Sobór nicejski miał duży autorytet na obszarze zarówno wschodniego, jak i zachodniego Cesarstwa, dlatego powtarzanie jego kanonów może świadczyć również o poszanowaniu tradycji. Niemniej należy pamiętać, że członkowie niższych stopni duchowieństwa, do subdiakona włącznie, mogli się żenić i mieć potomstwo. Wraz z awansem do diakonatu stawało się to, zgodnie z przepisami, niemożliwe, aczkolwiek nie oddalano małżonek, co także mogło potęgować pokusy. Celibat został wprowadzony znacznie później. Na temat bezżenności duchowieństwa wszystkich stopni por. S. Longosz, Patrystyczna motywacja celibatu, VoxP 1993-1995, t. 13-15, z. 24-29, s. 285-311.

30 Sancta synodus quae convenit in urbe Taurinorum die decimo Kalendas octobris, fratribus dilectissimis per Gallias et quinque provincias constitutis 9, SCh 241. Czytamy tam, że „qui [...] sunt ordinati vel in ministerio filios genuerunt”.

31 SCL IV, s. 121, can. 1, Toledo I (400).

32 Zagadnienie awansu kapłanów w Galii związane z zawieraniem związków małżeńskich opracowaliśmy już wcześniej, por. M. Wojcieszak, Moralność matżeńska oraz seksualna świeckich chrześcijan $w$ Galii w świetle postanowień późnoantycznych synodów galijskich, „Studia Pelplińskie” 2016, t. 69, s. 386-387.

33 SCL VIII, s. 316, can. 4, Aurelianum V (28 octobris 549).

34 SCL IV, s. 252, can. 126, Carthago (1 V 418).

35 Ibidem. 
prawdziwym pragnieniem uchronienia cnoty, a na ile decyzja rodziny o życiu zakonnym, tego - niestety - nigdy nie będzie dane nam się dowiedzieć. Wydaje się jednak, że Kościół w tej kwestii pomagał młodym dziewczętom, aby nie musiały żyć z zszargana opinią.

Ważne decyzje w interesujacym nas temacie wydali biskupi obradujący 13 listopada $442 \mathrm{r}$. w galijskim Vaison. W kanonie 9 odnieśli się w sposób ogólny do kwestii porzucanych dzieci. Usystematyzowali ten dość poważny, jak wynika z treści przepisu, problem. Biskupi, idąc za wytycznymi prawa cesarskiego ${ }^{36}$, uznali, że ze względu na miłosierdzie porzucone dzieci należą do tego, który zechciał się nimi zaopiekować ${ }^{37}$. Dodawali wszakże, rozszerzając ustawy rządzących, że taka osoba powinna wziąć Kościół na świadka, aby nikt nie rzucał fałszywych oskarżeń ${ }^{38}$, że dziecko zostało zabrane ze względu na materialny zysk, aby później stało się niewolnikiem ${ }^{39}$. Jak widzimy, hierarchowie Kościoła zdawali sobie sprawę, że ludzkie życie toczy się różnymi torami, a dzieci moga być poczęte w różnych niesprzyjających okolicznościach, takich jak zbyt liczna rodzina czy ubóstwo albo w wyniku cudzołóstwa lub gwałtu. Kanon ten dowodzi również, że na terenach Galii istniał problem porzucanych i niechcianych dzieci.

Uzupełnieniem tego przepisu jest kanon 10 - uznawano w nim za zabójcę każdego, kto - mimo wydanego przez Kościół świadectwa - rzucał oskarżenia na osobę, która zaopiekowała się porzuconym dzieckiem, i twierdził, że to jego dziecko, co prawda kiedyś niechciane, ale zmienił decyzję i teraz przejmuje nad nim opiekę ${ }^{40}$. W ten sposób przyznawał, że porzucił dziecko, a takie osoby traktowano w Kościele nader surowo.

Pewne uzupełnienie tych informacji stanowi zalecenie autorów Konstytucji apostolskich, którzy za obowiązek chrześcijańskiej rodziny dotkniętej problemem bezpłodności uznali adopcję porzuconego dziecka ${ }^{41}$. Wynika z tego, że kwestia porzucania niechcianych

36 Por. Cod. Th. V, 9, 1.

37 SCL VI, s. 23, can. 9, Vaison (13 XI 442).

38 Ibidem.

39 Niektórzy też sprzedawali dzieci, żeby uchronić się przed długami, por. D. Kasprzak, Kwestia bogactwa $i$ ubóstwa w Kościele imperialnym na Zachodzie w IV i V wieku. Próba syntezy zagadnienia, VoxP 2010, t. 56, s. 506.

40 SCL VI, s. 24, can. 10, Vaison (13 XI 442).

41 Constitutiones Apostolorum IV, 1, 1, SCL II, s. 97. 
dzieci istniała w całym Cesarstwie. Przez wydawanie takich przepisów próbowano szukać chrześcijańskich rodzin zastępczych dla porzucanych dzieci.

Biskupi zebrani na tzw. drugim synodzie w Arelate (dzisiejsze Arles), którego dokładnej daty nie znamy, ale odbył się pomiędzy 442 a 506 r., a jego kanony stanowiły zbiór różnych galijskich synodów mających miejsce w tym okresie, w kanonie 51 powtórzyli wszelkie zalecenia z przepisów 9 i 10 synodu w Vaison ${ }^{42}$. Dodali wszakże nową informację, dzięki której wiemy, jaki był sposób pozostawiania dzieci w interesujacym nas okresie - a mianowicie podrzucano dzieci przed budynki kościołów lub w ich okolicach ${ }^{43}$. Nie może to dziwić, ponieważ Kościół jako organizacja przejął w epoce późnego antyku działalność charytatywną i przez ówczesne społeczeństwo był postrzegany jako instytucja zajmująca się opieka nad sierotami i porzuconymi dziećmi, czego dowód widzieliśmy $\mathrm{w}$ wydawanych kanonach ${ }^{44}$. Ponadto wydanie kanonu 51 dowodzi, że problem na terenach Galii był dość powszechny. Możemy wiązać go z niepewną sytuacją ekonomiczna ówczesnego społeczeństwa, a szczególnie niższych warstw. We wschodniej części Imperium o porzucaniu dzieci i wynikających z tego trudnościach pisał głównie Bazyli Wielki ${ }^{45}$.

Pośrednie potwierdzenie porzucania dzieci znajdujemy w treści kanonu 16 wydanego na synodzie w Narbonie w 458/459 r. Dotyczył zagadnienia chrztu osób porzuconych przez rodziców, gdy były małymi dziećmi. Nie znały więc rodziców i w efekcie nie wiedziały, czy zostały ochrzczone ${ }^{46}$. Abstrahując od rozważań teologicznych, widzimy, że problem porzucania dzieci z różnych przyczyn, zwłaszcza na terenach Galii, istniał, i biskupi musieli sobie $\mathrm{z}$ tym radzić. Ubogich było wielu, a sytuację najuboższych musiały pogarszać

42 SCL VI, s. 32, can. 51, Arelate (post a. 442, ante a. 506).

43 Ibidem, gdzie czytamy „expositus ante ecclesiam”.

44 Również Bazyli Wielki upominał biskupów, żeby w swoich diecezjach dbali o opiekę nad sierotami w każdym wieku, por. Basilius Magnus, can. 56, SCL III, s. 53. Podobnie przekazali nam autorzy Konstytucji apostolskich, por. Constitutiones Apostolorum IV, 2, 1-2, SCL II, s. 97-98.

45 Basilius Magnus, can. 33, SCL III, s. 47. W tym kanonie Bazyli krytykował kobiety porzucające dzieci urodzone w podróży. Zostaje to wyjaśnione w kanonie 52, gdzie Bazyli opisuje kobiety udające się w podróż tylko po to, aby ukryć swój grzech, urodzić i porzucić dziecko, por. idem, can. 52, SCL III, s. 49.

46 SCL VI, s. 229, can. 16, Narbo (458/459). Synod ten jest znany z listu papieża Leona Wielkiego do biskupa Rustyka, por. Leo I Magnus, Ep. 167, PL 54. 
wysokie podatki nakładane przez rzymską administrację fiskalna oraz najazdy barbarzyńskie w połowie V stulecia, o czym donosili ówcześni chrześcijańscy pisarze galijscy ${ }^{47}$.

Biskupi w Narbonie zajęli się także problemem dzieci pochodzących ze związków konkubinatu. Uznali oni, że takie dziecko prawnie nie może zostać oficjalnie uznane ${ }^{48}$, chyba że kobieta zostałaby poślubiona $^{49}$. Było to ważne zagadnienie wpisujące się w kwestię niechcianych dzieci w interesujacym nas okresie. Z tego przepisu wynika bezsprzecznie, że Kościół zgadzał się z obowiąującym prawem cesarskim ${ }^{50}$.

W VI stuleciu, w czasach tworzenia się Europy wczesnośredniowiecznej na gruzach zachodniej części Imperium Rzymskiego, hierarchia kościelna również się zajęła interesującymi nas kwestiami. W południowogalijskim Agde (wówczas Agatha) biskupi nawiązali do niechcianych dzieci pozostawianych przed budynkami kościołów. W treści kanonu 24 czytamy, że wszelkie działania należy podejmować zgodnie z treścią kanonu 9 uchwalonego na synodzie w Vaison w $442 \mathrm{r} .{ }^{51}$ Wynika z tego, że problem nadal istniał, jednak nie był on na tyle poważny, żeby nad nim szczegółowo obradować i wystarczyło przypomnieć wcześniej ustalony przepis.

W 546 r. hiszpańscy hierarchowie, zebrani na synodzie w Leridzie (ówczesna Ilerda) pod władzą Wizygotów, zajęli się kwestia aborcji niechcianych dzieci. W kanonie 2, który dotyczył

47 Por. Salvianus, Adversus avaritiam IV, IV, 19, PL 53; Sulpicius Severus, Dialog II, 1, 1, CSEL 1 (gdzie możemy przeczytać, że żebrak w mieście jest widokiem normalnym, co oznacza, że musiało być ich sporo); Valerianus, Sermo 1, 6, PL 52 (wielu ubogich w regionie Cimelium nieopodal Nicei, skąd pochodził Walerian); idem, Sermo 9, 1; Constantius Lugdunensis, Vita S. Germani 35, SCh 112 (gdzie żyjący już w VI w. św. German sam dawał przykład, wspierając wiele osób żyjących w nędzy, co pozwala nam stwierdzić, że po upadku struktur politycznych w zachodniej części Cesarstwa sytuacja społeczna nie uległa znaczącej zmianie).

48 Can. 4, Narbo (458/459), SCL VI, s. 227, gdzie czytamy: „,non omnis mulier iuncta viro uxor est viri, quia nec omnis filius haeres est patris". Konkubina to nie żona, zatem dziecko pozostaje w świetle prawa bękartem, por. SCL VI, s. 227-228, can. 5, can. 6, can. 13, Narbo (458/459).

49 Por. Decretum Gratiani c. XXXII, 2, 12 (1123), CIC I.

50 Z kolei w wersji arabskiej kanonów Hipolita zredagowanych w I poł. IV w. odnajdujemy próbę ochrony dzieci pochodzących ze związku konkubinatu. Zgodnie z treścią przepisu, jeśli chrześcijanin zostawił kobietę, z którą miał dziecko, i ożenił się z inną, powinien być poddany surowemu osądowi oraz niedopuszczony do komunii z Kościołem na czas przewidziany dla zabójców, por. Hippolytus (versio arabica), can. 16, SCL III, s. 185.

51 SCL VIII, s. 8, can. 24, Agathe (11 septembris 506). 
duchowieństwa, choć jego treść mogła być również zastosowana do sytuacji świeckich, zajęto się szeroko rozumianą sprawą aborcji. Treść przepisu dotyczyła tych, którzy zabijali lub namawiali do zabijania dzieci poczętych w cudzołóstwie ${ }^{52}$. Z uchwalonego kanonu wynika, że przez aborcję rozumiano każde zabicie dziecka w łonie matki, a nawet zabójstwo dziecka dopiero co urodzonego, choć nie precyzowano, w którym momencie aborcja stawała się dzieciobójstwem ${ }^{53}$. Możemy podejrzewać, że biskupi mieli na myśli pierwsze chwile bezpośrednio po narodzinach dziecka. Poruszono również kwestię spędzania płodu w łonie matki za pomoca trucizny. Osoba, która parała się takim procederem, mogła otrzymać rozgrzeszenie i powrócić na łono Kościoła dopiero w momencie śmierci ${ }^{54}$. Z kolei cudzołożni kapłani zamieszani w aborcję własnego dziecka nie mogli otrzymać komunii z Kościołem prędzej niż po siedmiu latach pokuty. Również nie wolno im było sprawować poprzedniego urzędu ${ }^{55}$. Synod w Leridzie obradował w sprawach dyscyplinarnych duchowieństwa w państwie wizygockim, dlatego zapewne uznano za konieczne przypomnienie kwestii zwiazanych z aborcja, które uchwalili biskupi w Cesarstwie Rzymskim w IV stuleciu, o czym pisaliśmy wcześniej.

W kwestiach aborcji w VI stuleciu wypowiedział się również Cezary z Arles ${ }^{56}$. Podobnie jak hierarchia kościelna piętnował to zjawisko, które - wynika to z jego słów - było popularne wśród galijskich parafian ${ }^{57}$. Krytyce poddawał kobiety mające juz potomstwo, a podejmujące decyzję o przerwaniu kolejnej ciąży, ponieważ dręczyła je obawa o możliwość utrzymania kolejnego członka rodziny ${ }^{58}$. Przerywanie ciąży było powszechne i stanowiło jeden z głównych grzechów, z którym biskup Arles miał problem wśród wiernych ${ }^{59}$. Jego uwagi stanowią również dowód na żywe zainteresowanie hierarchii kościelnej w Galii zagadnieniem przerywania ciąży.

52 SCL VIII, s. 307, can. 2, Ilerda (546).

53 Ibidem, gdzie czytamy: „Hi vero qui male conceptos ex adulterio factos vel editos necare studuerint [...]”.

54 Ibidem.

55 Ibidem.

56 Na ten temat ogólnie por. L.K. Bailey, „These Are Not Men”: Sex and Drink in the Sermons of Caesarius of Arles, JECS 2007, vol. 15 (1), s. 23-43.

57 Por. Caesarius Arelatensis, Sermo, 44, 2-4, CCSL 103; ibidem, 51, 4.

58 Ibidem, 52, 4.

59 Ibidem, 1, 12 . 
Reasumując, Kościół w zachodniej części Cesarstwa Rzymskiego zajmował się problemem niechcianych dzieci, jednak nie był on często poruszany podczas synodów. Za niechciane uważano dzieci zrodzone $\mathrm{z}$ cudzołóstwa, porzucone $\mathrm{z}$ różnych przyczyn, a także te, które zostały poddane aborcji. Najwięcej miejsca w dokumentach synodalnych poświęcono sprawie aborcji oraz porzucaniu w różnych miejscach żywych dzieci. Widać po treści kanonów, że Kościół w epoce późnego antyku dążył do zmian w świadomości ludzi, twierdząc, że każde dziecko powinno się urodzić i nie można ich porzucać, a jeśli doszło do tego, to najlepiej byłoby zrobić to ante ecclesiam, co też wynikało z podejmowanej przez chrześcijańską hierarchią działań charytatywnych.

Inny problem stanowiły niechciane dzieci spłodzone przez wyższych duchownych, co nie licowało ze sprawowanymi przez nich godnościami oraz stanowiło później podstawę do wprowadzenia celibatu dla wszystkich stopni kapłanów. Dzieci pozostawały przy rodzicach, jednak możemy uznawać je w pewnym stopniu za niechciane, ponieważ przeszkadzały w karierze w strukturach duchowieństwa. Wśród „wyższych stopni duchowieństwa”, do których zaliczano diakonów, prezbiterów oraz biskupów, nie zakazywano posiadanie małżonek oraz dzieci, najczęściej z początków kariery duchownego. Dopiero po awansie nie wolno było współżyć z żonami i płodzić dzieci. Jeżeli dochodziło do takich nadużyć, wówczas albo degradowano kapłana oraz zabraniano awansować.

Kary ustanawiane przez Kościół za aborcję i porzucanie niechcianych dzieci były surowe - wieloletnia ekskomunika oraz pokuta. Cesarz Walentynian I dodatkowo postanowił, że każdy, kto zostanie złapany, porzucając dziecko, lub zostanie mu ten czyn udowodniony, będzie skazany na śmierć. Prawo to powtórzył w 529 r. Justynian, ustalając je dla świata chrześcijańskiego ${ }^{60}$. Państwo i Kościół dostrzegali zatem pojawiający się problem aborcji oraz porzucania dzieci, zwłaszcza nowo narodzonych, dlatego usiłowali zmniejszyć ten proceder, stosując wśród społeczeństwa wysokie kary. Powtarzanie różnych przepisów może jednak świadczyć o tym, że działania te nie zawsze były udane.

Najwięcej na temat porzucanych dzieci w interesujacym nas okresie możemy się dowiedzieć z dokumentów synodalnych ze zgromadzeń biskupów galijskich w połowie $\mathrm{V}$ stulecia. Może to wynikać 
z tego, że Galia była jedną z najuboższych prowincji zachodniej części Cesarstwa Rzymskiego, problem porzucania dzieci z powodów ekonomicznych mógł więc być tutaj szczególnie widoczny. Niemniej na tej podstawie nie jesteśmy w stanie stwierdzić, że w Galii porzucano dzieci częściej niż w pozostałych prowincjach.

Biskupi obradujacy na synodach nie podawali, dlaczego dzieci stawały się niechciane. Możemy tylko wnioskować z treści kanonów oraz znajomości ludzkiego zachowania, że zarówno aborcji, jak i porzucania dzieci dokonywano z powodu biedy i wszelkich zwiazanych z nią zjawisk, a także strachu przed ostracyzmem społecznym w przypadku cudzołóstwa lub niechęci posiadania potomstwa. Kościół nie tylko karał, ale także próbował chronić życie od momentu poczęcia oraz rozwijać sieć opieki nad porzuconymi dziećmi.

Zagadnienie to stanowi niewielki przyczynek do poznania życia codziennego społeczeństw zachodniej części Cesarstwa Rzymskiego w okresie późnego antyku oraz we wczesnym średniowieczu, kiedy to tworzyły się nowe struktury polityczne, gospodarcze i społeczne. Hierarchia kościelna nie poświęciła wiele miejsca kwestiom niechcianych dzieci, uznając zapewne, że obowiązujace przepisy cesarskie oraz synodalne wyczerpywały temat. W sytuacjach pilnego zapotrzebowania wydawano odpowiednie przepisy na zgromadzeniach biskupich.

\begin{abstract}
The Church of Late Antiquity and the Early Middle Ages in Relation to the Issue of Unwanted Children: the Desicions of Western Assemblies of Bishops
\end{abstract}

The author analyses canon laws about abortion and unwanted children, which were issued by western Roman assemblies of bishops in late antiquity and the early Middle Ages (between the fourth and sixth centuries). Such problems were not mentioned often, but the Church instituted severe penalties for abortion and abandoning unwanted children. Bishops did not discuss reasons for abortion and abandoning children. They only penalized the results, but we can comment on the causes of such behaviours, analysing the contents of canon laws and using other sources from the epoch, like the writings of the Church Fathers and the Codes of Theodosius and Justinian. We can say that problems like abortion or abandoning unwanted children existed in various places and they were a subject of the local bishops' 
concern. The church hierarchy did not devote much attention to the issue of unwanted children, considering that imperial and synodal regulations were adequate to deal with those problems. The issues analyzed here constitute a small contribution to our knowledge of the everyday life of the societies of the western part of the Roman Empire in late antiquity and in the early Middle Ages. 